\title{
Maternal mortality from hemorrhage in the State of Santa Catarina, Brazil
}

\author{
MORTALIDADE MATERNA POR HEMORRAGIA NO ESTADO DE SANTA CATARINA, BRASIL \\ MORTALIDAD MATERNA POR HEMORRAGIA OCURRIDA EN EL ESTADO DE SANTA \\ CATARINA, BRASIL
}

\author{
Haimée Emerich Lentz Martins ${ }^{1}$, Maria de Lourdes de Souza ${ }^{2}$, María Angélica Arzuaga-Salazar ${ }^{3}$
}

\begin{abstract}
Hemorrhage represents a set of causes that focuses on women during the pregnancy and puerperal period, and that, with improper attention, results in death. The authors aimed to analyze maternal deaths related to hemorrhage that occurred in the state of Santa Catarina, Brazil. The data were obtained from the Mortality Information System and Live Births Information System from the Brazilian Ministry of Health. This was a descriptive study, in which 491 maternal deaths that occurred in the period 1997-2010 were analyzed. Of these, 61 were related to hemorrhage, corresponding to $12.42 \%$; postpartum hemorrhage was the most prevalent cause, with 26 deaths, followed by placental abruption with 15 , representing $67.21 \%$ of the cases. The maternal mortality from hemorrhage is a public health problem in the state of Santa Catarina, due to its high prevalence and the fact that its underlying causes are preventable.
\end{abstract}

\section{DESCRIPTORS}

Maternal mortality

Causes of death

Postpartum hemorrhage

Obstetrical nursing

\section{RESUMO}

A hemorragia representa um conjunto de causas que incide sobre a mulher durante o ciclo grávido-puerperal e com atenção indevida resulta em morte. Os autores têm como objetivo analisar as mortes maternas relacionadas à hemorragia ocorridas no estado de Santa Catarina, Brasil. Os dados foram obtidos junto ao Sistema de Informações de Mortalidade e Sistema de Informações sobre Nascidos Vivos do Ministério da Saúde do Brasil. Estudo descritivo no qual foram analisados 491 óbitos maternos ocorridos no período de 1997 a 2010. Desses, 61 estiveram relacionados à hemorragia, correspondendo a 12,42\%, sendo a hemorragia pós-parto a causa mais prevalente, com 26 óbitos, seguida por descolamento prematuro de placenta com 15 , representando $67,21 \%$ dos casos. A mortalidade materna por hemorragia é um problema de saúde pública no Estado de Santa Catarina, devido a sua alta prevalência e as causas básicas são preveníveis.

\section{DESCRITORES \\ Mortalidade materna \\ Causas de morte \\ Hemorragia pós-parto \\ Enfermagem obstétrica}

\begin{abstract}
RESUMEN
La hemorragia representa un conjunto de causas que incide sobre la mujer durante el ciclo gestacional y puerperal, y con una atención indebida resulta en la muerte. Los autores tienen como objetivo analizar las muertes maternas relacionadas con la hemorragia, ocurridas en el Estado de Santa Catarina, Brasil. Los datos fueron obtenidos del Sistema de Información de Mortalidad y Sistema de Información sobre Nascidos Vivos, del Ministerio de Salud del Brasil. Estudio descriptivo en el cual fueron analizados 491 muertes maternas, durante el período de 1997 al 2010. De los cuales, 61 estuvieron relacionadas con la hemorragia, correspondiendo a $12,42 \%$, siendo la hemorragia post-parto la causa más prevalente con 26 muertes, seguida por el desprendimiento prematuro de placenta con 15 , representando el $67,21 \%$ de los casos. La mortalidad materna por hemorragia es un problema de salud pública en el Estado de Santa Catarina, debido a su alta prevalencia y las causas básicas que son prevenibles.
\end{abstract}

\section{DESCRIPTORES \\ Mortalidad materna \\ Causas de muerte \\ Hemorragia postparto \\ Enfermería obstétrica}

${ }^{1}$ Nurse. Doctoral student at the Nursing Graduate Program, Federal University of Santa Catarina. Nurse at the maternity hospital Carmela Dutra, State Health Secretary, Santa Catarina. Member of the Caring and Comforting Research Group. Florianópolis, SC, Brazil. haimeelentz@hotmail.com ${ }^{2}$ Nurse, Doctorate in Public Health. Collaborating Professor at the Nursing Graduate Program, Federal University of Santa Catarina. Member of the Caring and Comforting Research Group. President of REPENSUL. lourdesr@repensul.ufsc.br ${ }^{3}$ Nurse, Doctorate in Nursing, Federal University of Santa Catarina. Member of the Caring and Comforting Research Group. Professor at Antioquia University, Colombia. marzuaga@udea.edu.co

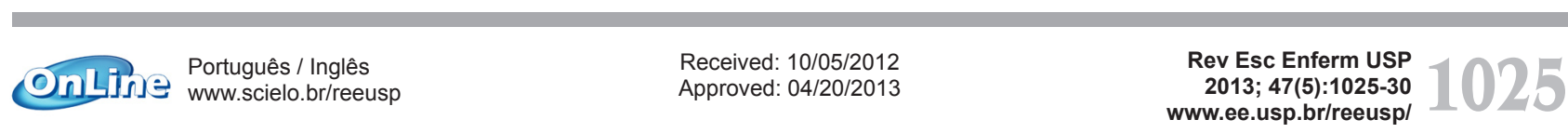




\section{INTRODUCTION}

Postpartum hemorrhage is excessive blood loss associated with labor or birth of an infant. Defined as blood loss greater than $500 \mathrm{ml}$ or as an amount which adversely affects maternal physiology, such as: blood pressure and hematocrit. It is divided into two categories: immediate (within 24 hours after birth) or late (24 hours after birth) ${ }^{(1)}$.

Classically, postpartum hemorrhage (PPH) is defined as blood loss greater than $500 \mathrm{ml}$ in vaginal delivery, and $1000 \mathrm{ml}$ in a cesarean delivery ${ }^{(2)}$. In practice, the amount of blood loss is estimated subjectively, and severity of hemorrhage is frequently underestimated ${ }^{(3)}$.

The most common cause of PPH is uterine atony, a complication present in one out of every 20 births. The risk factors for atony are: multiple pregnancy, hidramnios, macrosomia, precipitated or prolonged labor, chorioamnionitis or simply the inability to contract the muscle caused by the use of tocolytic or general anesthesia( ${ }^{(4)}$.

In one study ${ }^{(3)}$ conducted in Argentina and Uruguay, PPH was classified as moderate, in which the blood loss was at least $500 \mathrm{ml}$, and severe, in which the loss was $1,000 \mathrm{ml}$. In the same study, the following risk factors for $\mathrm{PPH}$ were identified: retained placenta (33.3\%), multiple pregnancy (20.9\%), macrosomia (18.6\%), episiotomy (16.2\%) and need for perineal suturing (15.0\%). And in the case of severe PPH: retained placenta (17.1\%), multiple pregnancy $(4.7 \%)$, macrosomia $(4.9 \%)$, induction of labor (3.5\%), need for perineal suturing $(2,5 \%)^{(3)}$.

Maternal death associated with hemorrhage is common in developing countries, where women are most exposed to risk as well as unfavorable economic conditions ${ }^{(4)}$.

The causes of maternal deaths in Brazil, regardless of the region, are related to hypertensive diseases and hemorrhage, alternating the position in some states, without analysis of determinants of the maternal deaths ${ }^{(5)}$. In Santa Catarina, a state in southern Brazil, in the whole bibliography consulted regarding maternal death, the maternal mortality ratio and the causes that triggered this event are presented. The results showed that a higher proportion of maternal deaths were direct obstetrical deaths, and that hemorrhage accounted for $30.3 \%^{(6-8)}$.

The basic causes of maternal death are difficult to estimate, especially in developing countries, where systems of records are inadequate and/or nonexistent. The data are associated to the uncertainty and difficulty in clearly identifying the cause of death such as maternal(9). The death certificate is one of the sources for obtaining the basic cause of maternal death, in which the cause of death must be recorded in a clear and accurate form.
Since the year 1997, the registration of maternal death became the duty of states and municipalities in Brazil, for the determination of a normative act that declared maternal death to be a compulsory notification event. The measurement of maternal mortality can result in adequate definition of public policies. In the international context, qualified services and the improvement of obstetric care in health services to reduce maternal mortality are emphasized ${ }^{(10-11)}$.

Considering the present scenario and that the Brazilian government is a signatory to the pact to reduce maternal mortality, related to one of the millennium development goals ${ }^{(10)}$, this study sought to answer the following question: how does maternal mortality from hemorrhage in the State of Santa Catarina present, and what does it reveal?

\section{METHOD}

This was a population-based, descriptive, retrospective, time series study, in the State of Santa Catarina. Data were collected from the DATASUS/Brazilian Ministry of Health, Mortality Information System - MIS $^{(12)}$ and the Live Birth Information System - LBIS ${ }^{(13)}$, relative to women living in Santa Catarina, in the period of 1997 to 2010.

Deaths were identified from information contained in the death certificate, such as: year, region of occurrence and underlying cause, coded conforming to the ICD 10th revision ${ }^{(14)}$ in which diagnoses related to hemorrhage are defined. Therefore, we included deaths whose cause, by category, were classified as the following codes: 000 ectopic pregnancy, 043 placental disorder, 044 placenta previa, 045 placental abruption, 046 ante-partum hemorrhage not otherwise classified (NOC), $\mathrm{O} 67$ Labor and delivery complicated by intrapartum hemorrhage, (NOC), 072 postpartum hemorrhage.

The collected data were reviewed applying the correction factor resulting from research conducted in the Brazilian reality ${ }^{(15)}$. With the revised data, the Maternal Mortality Ratio from Hemorrhage (MMRH) was calculated for each year of the time series, and the percentage of deaths from hemorrhage conforming to the basic cause by ICD 10 category $^{(14)}$. The MMRH was calculated adopting the formula: number of deaths from maternal cause related to hemorrhage, about the number of live births in the period, multiplied by a constant $100,000^{(16)}$.

This study was developed in the context of Catarinas Macroproject: birth, life and death, approved by the Ethics Committee of the Federal University of Santa Catarina (CEPSH-UFSC), Protocol No. 209/2008, extended to 
July of 2012, observing that which determined Resolution No. 196/1996, of the Brazilian Ministry of Health.

\section{RESULTS}

In the period from 1997 to 2010, in the State of Santa Catarina, 61 deaths related to hemorrhage were identified, representing $12.42 \%$ of total maternal deaths. The data, by macroregion, about maternal deaths related to hemorrhage and its percentage distribution are shown in Table 1 . The percentage ranged from $25.53 \%$ in the macroregion of Itajaí Valley to 7.89 in the macroregion of Serra Catarinense.

The data presented in Table 2 refer to maternal deaths from hemorrhage in specific categories according to ICD $10^{(14)}$, occurred in the State of Santa Catarina, in the period 1997-2010. Of the 61 maternal deaths from hemorrhage recorded in the period, the largest percentage was $42.62 \%$ of postpartum hemorrhage and the smallest was $1.64 \%$ disorder of the placenta.

The MMRH by macroregion of the state of Santa Catarina, in the period of 1997 to 2010, was 5.73 as shown in Table 3. The most RMMH by macroregion was found in the Itajaí River Mouth, with a value of 9.21 , and the lowest was in the northeast macroregion, with 3.22.

\section{DISCUSSION}

Hemorrhage represents a set of causes that lead to a direct obstetrical maternal deaths, that is, one that occurs due to obstetric complications during pregnancy, childbirth or the postpartum period, due to interventions, omissions, incorrect treatment or a chain of events resulting from any of these causes ${ }^{(16)}$.

Hemorrhage during pregnancy, childbirth or the postpartum period is a set of causes of maternal death, that in ICD $10^{(14)}$ were grouped into categories. Variations were found in this study that demonstrated the need for attention, due to the action of indirect factors, such as incorrect completion of the investigation forms and of the death certificate. Inadequate records may result in numbers that do not adequately express the variations in the risk of these deaths ${ }^{(7)}$.

In the present study, the percentage of maternal deaths from hemorrhage in the state of Santa Catarina was $12.42 \%$, as shown in Table 1 . The percentage differences observed in all macroregions may indicate differences in the quality of existing health services as well as in the quality of completion of the death certificate. The highest percentage of deaths was identified in the macroregion of

Table 1 - Maternal mortality specific for hemorrhage, occurring in the State of Santa Catarina by health macroregion, in the period 1997-2010

\begin{tabular}{|c|c|c|c|c|c|c|c|c|c|c|c|c|c|c|c|c|c|c|}
\hline \multirow{3}{*}{$\begin{array}{l}\text { Santa Catarina by health } \\
\text { macroregion }\end{array}$} & \multicolumn{18}{|c|}{ Maternal Mortality } \\
\hline & \multicolumn{15}{|c|}{ Specific for Hemorrhage (E) } & \multicolumn{3}{|c|}{ General (G) } \\
\hline & $\hat{a}$ & $\stackrel{\infty}{\circ}$ & ڤ & 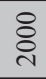 & $\bar{\AA}$ & §ิ & ֻิ & ¿ั & ๕ి & 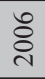 & $\hat{\text { है }}$ & 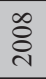 & ஓे & $\stackrel{\circ}{\stackrel{1}{~}}$ & $\mathrm{~N}$ & $\mathrm{~N}$ & $\%$ & $\begin{array}{c}\% \\
\mathrm{E} / \mathrm{G}\end{array}$ \\
\hline Itajaí Valley & 3 & - & 1 & 1 & - & 5 & 2 & - & - & - & - & - & - & - & 12 & 47 & 9,57 & 25,53 \\
\hline South & - & - & 1 & 2 & 1 & - & 1 & 2 & - & 1 & 2 & - & - & - & 10 & 75 & 15,27 & 13,33 \\
\hline Itajaí River Mouth & - & - & 1 & - & - & 2 & - & 2 & - & - & 3 & - & - & - & 8 & 50 & 10,18 & 16,00 \\
\hline Midwest & - & - & - & - & - & - & 1 & - & 5 & 1 & - & 1 & - & - & 8 & 67 & 13,65 & 11,94 \\
\hline Great Florianópolis & - & 2 & - & 1 & - & - & - & - & - & 1 & 2 & - & - & - & 6 & 59 & 12,02 & 10,17 \\
\hline Great West & - & - & 2 & - & 1 & - & - & 1 & 1 & - & - & - & - & - & 5 & 63 & 12,83 & 7,94 \\
\hline Northeast & - & - & 1 & - & - & - & 1 & - & 1 & - & - & - & 1 & 1 & 5 & 60 & 12,22 & 8,33 \\
\hline Northern Plateau & - & - & - & - & - & - & - & - & - & 2 & 1 & - & 1 & - & 4 & 32 & 6,52 & 12,50 \\
\hline Serra Catarinense & - & 1 & - & 1 & - & - & 1 & - & - & - & - & - & - & - & 3 & 38 & 7,74 & 7,89 \\
\hline Total & 3 & 3 & 6 & 5 & 2 & 7 & 6 & 5 & 7 & 5 & 8 & 1 & 2 & 1 & 61 & 491 & 100 & 12,42 \\
\hline
\end{tabular}

Source: SIM/DATASUS ${ }^{(12)}$

Table 2 - Maternal death specific to hemorrhage, by categories of basic cause, occurring in the state of Santa Catarina, in the period 1997-2010

\begin{tabular}{|c|c|c|c|c|c|c|c|c|c|c|c|c|c|c|c|c|}
\hline ICD 10 CATEGORY & $\hat{\widehat{a}}$ & $\stackrel{\circ}{2}$ & 亏े & ஓ્ิ & ฮิ & 气ิ & 气ิ & ঙั & 气ิે & ‡ั̆ & 气ิે & $\stackrel{\infty}{\stackrel{\sim}{~}}$ & ڤิ & $\stackrel{ }{\overline{\mathrm{N}}}$ & हूँ & $\mathbf{N}$ \\
\hline O72 Postpartum hemorrhage & 1 & 1 & 3 & 1 & 1 & 5 & 1 & 2 & 2 & 3 & 3 & 0 & 2 & 1 & 26 & 42,62 \\
\hline O45 Placental abruption & 1 & 1 & 2 & 2 & 1 & 1 & 1 & 2 & 1 & 0 & 2 & 1 & 0 & 0 & 15 & 24,59 \\
\hline O00 Ectopic Pregnancy & 0 & 0 & 0 & 2 & 0 & 0 & 1 & 1 & 3 & 0 & 0 & 0 & 0 & 0 & 7 & 11,48 \\
\hline O44 Placenta previa & 1 & 0 & 0 & 0 & 0 & 0 & 1 & 0 & 0 & 1 & 2 & 0 & 0 & 0 & 5 & 8,20 \\
\hline O46 Antepartum hemorrhage NOC & 0 & 0 & 1 & 0 & 0 & 1 & 1 & 0 & 0 & 1 & 0 & 0 & 0 & 0 & 4 & 6,56 \\
\hline $\begin{array}{l}\text { O67 Labor and delivery complicated } \\
\text { by intrapartum hemorrhage NOC }\end{array}$ & 0 & 0 & 0 & 0 & 0 & 0 & 1 & 0 & 1 & 0 & 1 & 0 & 0 & 0 & 3 & 4,92 \\
\hline O43 Placenta disorder & 0 & 1 & 0 & 0 & 0 & 0 & 0 & 0 & 0 & 0 & 0 & 0 & 0 & 0 & 1 & 1,64 \\
\hline Total & 3 & 3 & 6 & 5 & 2 & 7 & 6 & 5 & 7 & 5 & 8 & 1 & 2 & 1 & 61 & 100 \\
\hline
\end{tabular}

Source: SIM/DATASUS(12) 
Itajaí Valley, at $25.53 \%$. This high death rate may be associated with the lack of a system of reference and counter-reference that did not identify the risk of pregnancy, childbirth and postpartum, poor planning and neglect of pregnant women ${ }^{(8)}$.

Maternal death from hemorrhage is the worst obstetrical outcome, and in Recife, $25.4 \%$ of admissions in obstetric ICU were for this cause ${ }^{(17)}$. In Syria, a study conducted about the causes of maternal death showed that $88 \%$ of deaths were directly obstetrical, $65 \%$ of which related to hemorrhage, and that death occurred during labor and delivery. The inability and lack of clinical competence in providing care were the triggering factors in $54 \%$ of these death ${ }^{(18)}$.
Data presented in Table 2, according to the categories of ICD $10^{(14)}$, showed that postpartum hemorrhage was the most frequent cause in the series studied, with a proportional variation different from placental abruption, which was the second cause.

Postpartum hemorrhage occurs in approximately $4 \%$ of vaginal deliveries and estimates are that $25 \%$ have death as an outcome ${ }^{(19)}$. Furthermore, a study about maternal death that adopted the near miss ${ }^{(a)}$ as a reference showed that hemorrhage is among the most common events, preceded by hypertensive complications, and that the maternal mortality rates were reduced based on knowledge about how to intervene on this problem ${ }^{(22)}$.

Table 3 - MMRH occurring in the state of Santa Catarina by health macroregion, in the period of 1997 to 2010

\begin{tabular}{|c|c|c|c|c|c|c|c|c|c|c|c|c|c|c|c|}
\hline \multirow[b]{2}{*}{$\begin{array}{l}\text { Santa Catarina health } \\
\text { macroregion }\end{array}$} & \multicolumn{15}{|c|}{ Specific Maternal Mortality Ratio by Hemorrhage (MMRH) } \\
\hline & $\hat{\sigma}$ & $\stackrel{\circ}{\sigma}$ & बे & 今్ & 亏ั) & 气ิ & 气ิે & ङ્ڤે & 气ิે & 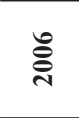 & 今ે̀ิ & $\stackrel{\infty}{\stackrel{\sim}{*}}$ & હेે & 올 & 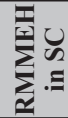 \\
\hline Itajaí River Mouth & - & - & 15,80 & - & - & 34,09 & - & 32,50 & - & - & 46,50 & - & - & - & 9,21 \\
\hline Itajaí Valley & 26,80 & - & 9,12 & 9,59 & - & 52,30 & 21,60 & - & - & - & - & - & - & - & 8,53 \\
\hline Midwest & - & - & - & - & - & - & 12,40 & - & 60,60 & 12,30 & - & 12,80 & - & - & 7,01 \\
\hline South & - & - & 7,80 & 16,60 & 8,80 & - & 9,63 & 19,20 & - & 9,60 & 19,66 & - & - & - & 6,52 \\
\hline Northern Plateau & - & - & - & - & - & - & - & - & - & 38,60 & 19,61 & - & 21,20 & - & 5,67 \\
\hline Serra Catarinense & - & 19,40 & - & 22,04 & - & - & 24,05 & - & - & - & - & - & - & - & 4,68 \\
\hline Great West & - & - & 16,80 & - & 9,84 & - & - & 10,94 & 11,38 & - & - & - & - & - & 3,50 \\
\hline Great Florianópolis & - & 15,02 & - & 7,07 & - & - & - & - & - & 7,74 & 15,35 & - & - & - & 3,23 \\
\hline Northeast & - & - & 8,34 & - & - & - & 9,90 & - & 9,37 & - & - & - & 8,60 & 8,87 & 3,22 \\
\hline RMMEH in SC/Ano & 2,98 & 3,82 & 6,43 & 6,14 & 2,07 & 9,60 & 8,62 & 6,96 & 9,04 & 7,58 & 11,24 & 1,42 & 3,31 & 0,99 & 5,73 \\
\hline
\end{tabular}

A review study about expectant and active management of the third stage of labor showed that active management in labor was introduced in an attempt to reduce hemorrhage, a major cause of death ${ }^{(23)}$. In addition, the authors addressed active management as an effective action for women with high risk for hemorrhage, who may succumb during childbirth due to the absence of qualified personnel and supplies, such as uterotonic medication.

A technology for the reduction of maternal mortality from hemorrhage are the basic emergency obstetrical services (parenteral oxytocin, antibiotics and anticonvulsants, assisted deliveries, manual removal of the placenta, removal of retained products) and, if necessary, other comprehensive emergency obstetric services (basic services, caesarean section or blood transfusions) ${ }^{(24)}$. In Malaysia, a study showed that maternal mortality rates decreased more among women referred for emergency obstetric care than among those who presented themselves without referral to the health center of the district ${ }^{(25)}$.

The MMRH presented irregularities, as can be seen from the data presented in Table 3. The values obtained did not have uniform variation of increase or decrease, there may not be a trend exhibited ${ }^{(6)}$. In the series of this study, MMRH was 5.73 maternal deaths from hemorrhage for every 100,000 live births, showing that the risk for death that a pregnant woman had from hemorrhage was five times higher than from other causes.
In the present study, the distribution of MMRH in the Itajaí River Mouth macroregion reached the value of $9.21 / 100,000$ live births for the series studied, above the mean of the state of Santa Catarina. This result may be associated with deficiencies in health care in urgent and emergency obstetrical care, the inexistence of systems of reference and counter-reference, among others.

Studies about maternal death related to hemorrhage confirmed that MMR was an important indicator for assessing the event and the quality of maternal-infant care services ${ }^{(6,8)}$.

\section{CONCLUSION}

The analysis of maternal deaths from hemorrhage in the state of Santa Catarina revealed that it was a clinical manifestation whose occurrence was linked to regional conditions. The highest percentage $(25.53 \%)$ in the macroregion of Itajai may be associated with difficulties in identifying women with high risk pregnancy, the lack of referral services and early identification, with proper referral of pregnant women by the primary care services.

In the series of this study, the MMRH was 5.73 maternal deaths from hemorrhage for each 100,000 live births,

${ }^{a}$ An almost death for any complications during pregnancy, childbirth or the postpartum period, but that survived due to chance or good hospital care ${ }^{(20-21)}$.
Maternal mortality from hemorrhage in the State of Santa Catarina, Brazil Martins HEL, Souza ML, Dalmas JC, Arzuaga-Salazar MA 
indicating that the risk that a pregnant woman has of dying from hemorrhage was five times greater than from other causes. The high maternal mortality with unstable $\mathrm{MMRH}$ revealed the risk of death from hemorrhange to which women were exposed in all geographical regions in the state of Santa Catarina. This showed that the event was not adequately controlled in the context of health care services, despite the existence of clinical and surgical technologies. It also demonstrated the need for the development of skills for the adequate management of the third stage of labor.

\section{REFERENCES}

1. Hofmeyr GJ, Abdel-Aleem H, Abdel-Aleem MA. Uterine massage for preventing postpartum haemorrhage. Cochrane Database Syst Rev. 2008;(3):CD006431.

2. Andolina K, Daly S, Roberts N, Tolosa J, Wapner R. Objective measurement of blood loss at delivery: is it more than a guess? Am J Obstet Gynecol. 1999;180:S69.

3. Sosa CG, Althabe F, Belizán JM, Buekens P. Risk factors for postpartum hemorrhage in vaginal deliveries in a Latin-American population. Obstet Gynecol. 2009;113(6):1313-9.

4. Khan K, Wojdyla D, Say L, Gülmezoglu AM, Van Look PF. WHO analysis of causes of maternal death: a systematic review. Lancet. 2006;367(9516):1066-74.

5. Morse ML, Fonseca SC, Barbosa MD, Calil MB, Eyer FPC. Mortalidade materna no Brasil: o que mostra a produção científica nos últimos 30 anos. Cad Saúde Pública. 2011;27(4):623-38.

6. Souza ML. Coeficiente de mortalidade materna segundo tipo de óbito, grupo etário, paridade, local de residência e tipo de parto: obituário hospitalar, 1975 a 1979. Florianópolis, SC (Brasil). Rev Saúde Pública. 1983;17(4):279-89.

7. Peixoto HCG, Martins HEL, Gregório VRP, Knobel R. Perfil da mortalidade materna em Santa Catarina. Enferm Global [Internet]. 2005 [citado 2008 ago. 29];(8):1-11. Disponível em: http://revistas.um.es/eglobal/article/view/326

8. Souza ML, Burgardt D, Ferreira LAP, Bub MBC, Monticelli M, Lentz HE. Girls from Santa Catarina: losing your life to become a mother. Rev Esc Enferm USP [Internet]. 2010 [cited 2012 Sept 19];44(2):318-23. Available from: http://www.scielo.br/ pdf/reeusp/v44n2/en_11.pdf

9. Sousa MH, Cecatti JG, Hardy EE, Serruya SJ. Morte materna declarada e o relacionamento de sistemas de informações em saúde. Rev Saúde Pública. 2007;41(2):181-9.

10. World Health Organization (WHO), Global Health Observatory (GHO). Maternal and reproductive health [Internet]. Geneva: WHO; 2011 [cited 2012 Jan 17]. Available from: http://www.who.int/gho/maternal_health/en/
The results of time series studies represent a contribution to health professionals, so they can reflect on the reality in which they work. They reveal the need to adopt protocols that include clinical and social observation, of a modality that can offer care to women in the time it is needed. The need for sensitization of professionals is also revealed, to develop a culture of innovation in healthcare practice to incorporate the scientific and technological advances, as an example the integrated protocols, so that there will be a reduction in maternal mortality from hemorrhage.

11. Brasil. Ministério da Saúde. Pacto Nacional pela Redução da Mortalidade Materna e Neonatal [Internet]. Brasília; 2004 [citado 2008 ago. 29]. Disponível em: http://189.28.128.100/ dab/docs/publicacoes/informes/psfinfo22.pdf

12. Brasil. Ministério da Saúde. DATASUS. Sistema de Informações sobre Mortalidade (SIM). [Internet]. Brasília; 2011 [citado 2012 fev. 12]. Disponível em: http://www2.datasus. gov.br/DATASUS/index.php?area=040701

13. Brasil. Ministério da Saúde. Sistema de Informações sobre Nascidos Vivos (SINASC). [Internet]. Brasília; 2011 [citado 2012 fev. 12]. Disponível em: http://portal.saude.gov.br/ portal/saude/visualizar_texto.cfm?idtxt $=21379$

14. Organização Mundial da Saúde (OMS). CID-10 - Classificação Estatística Internacional de Doenças e Problemas Relacionados à Saúde: 10ạ rev. São Paulo: EDUSP; 2001.

15. Luizaga CTM, Gotlieb SLD, Mello Jorge MHP, Laurenti R. Mortes maternas: revisão do fator de correção para os dados oficiais. Epidemiol Serv Saúde. 2010;19(1):7-14.

16. Brasil. Ministério da Saúde; Secretaria de Atenção à Saúde, Departamento de Ações Programáticas Estratégicas. Manual dos Comitês de Morte Materna. 3ạ ed. Brasília; 2007.

17. Amorim MMR, Katz L, Valenca M, Araujo DE. Morbidade materna grave em UTI obstétrica no Recife, Região Nordeste do Brasil. Rev Assoc Med Bras. 2008;54(3):261-6.

18. Bashour H, Abdulsalam A, Jabr A, Cheikha S, Tabbaa M, Lahham $M$, et al. Maternal mortality in Syria: causes, contributing factors and preventability. Trop Med Int Health. 2009;14(9):1122-7.

19. Mousa HA, Alfirevic Z. Treatment for primary postpartum haemorrhage. Cochrane Database Syst Rev. 2007;(1):CD003249.

20. Stones W, Lim W, Al-Azzawi F, Kelly M. An investigation of maternal morbidity with identification of life-threatening “near miss" episodes. Health Trends. 1991;23(1):13-5. 
21. Pattinson R, Hall M. Near misses: a useful adjunct to maternal death enquiries. Br Med Bull. 2003;67:231-43.

22. Ali AA, Khojali A, Okud A, Adam GK, Adam I. Maternal nearmiss in a rural hospital in Sudan. BMC Pregnancy Childbirth. 2011 Jun 29;11:48.

23. Prendiville WJP, Elbourne D, McDonald SJ. Active versus expectant management in the third stage of labour. Cochrane Database Syst Rev. 2009;(3):CD000007.
24. Paxton A, Maine D, Freedman L, Fry D, Lobis S. The evidence for emergency obstetric care. Int J Gynaecol Obstet. 2005;88(2):181-93.

25. Fournier P, Dumont A, Tourigny C, Dunkley G, Dramé S. Improved access to comprehensive emergency obstetric care and its effect on institutional maternal mortality in rural Mali. Bull World Health Organ. 2009;87(1):30-8.

\section{Acknowledgements}

Financial support of the Network Management Project: Prevention of Maternal and Neonatal Mortality. PPSUS Notice 003/2012. FAPESC - Term of Agreement 13075/2012-3. 